\title{
ПРОЦЕДУРА ВИВЧЕННЯ ВАЛІДАЦІЙНОГО ПАРАМЕТРА \\ “СТАБІЛЬНІСТЬ ПРИ РОЗВЕДЕННІ” АНАЛІТИЧНОЇ МЕТОДИКИ КІЛЬКІСНОГО ВИЗНАЧЕННЯ ДЕЯКИХ АНТИГІПЕРТЕНЗИВНИХ АНАЛІТІВ У БІОЛОГІЧНИХ РІДИНАХ ДЛЯ ПРОВЕДЕННЯ ФАРМАКОКІНЕТИЧНИХ ДОСЛІДЖЕНЬ
}

Вступ. Біоаналітична методологія є основоположником досліджень з вивчення біоеквівалентності й терапевтичного моніторингу лікарських засобів, тому основну увагу при вивченні фрармакокінетики та біоеквівалентності потрібно приділяти розробці й валідації біоаналітичних методик аналізу.

Мета дослідження - провести експериментальне вивчення валідаційного параметра "стабільність при розведенні" аналітичної методики кількісного визначення амлодипіну, бісопрололу та еналаприлу в плазмі крові для виконання фрармакокінетичних досліджень.

Методи дослідження. Біоаналітична методика визначення амлодипіну, бісопрололу та еналаприлу ґрунтується на ВEPX/MC/MC аналізі аналітів у досліджуваних розчинах, отриманих із зразків плазми після попереднього осадження білків.

Результати й обговорення. У цій роботі описано валідаційний параметр "стабільність при розведенні”. Розроблено електронні протоколи з використанням Microsoft Excel, в яких передбачено поля для введення даних. Для розробки процедури визначення та оцінки dilution integrity виконано модельний експеримент. Бланкові зразки плазми розбавляли 2- і 4-кратні розведення при шести визначеннях. Розведення зразків не вплинуло на правильність та прецизійність розробленої методики. Валідаційний параметр "стабільність при розведенні" (dilution integrity) незаслужено обділено увагою в керівництвах з валідації біоаналітичних методик - можливість розведення зразків дозволяє звужувати діапазон застосування методики і використовувати для калібрування більш просту модель, отримувати кращі показники лінійності, правильності та прецизійності; розробляти методику для низьких концентрацій і використовувати ї як універсальну.

Висновки. Проведено експериментальне вивчення валідаційного параметра "стабільність при розведенні" аналітичної методики кількісного визначення амлодипіну, бісопрололу та еналаприлу в плазмі крові для виконання фрармакокінетичних досліджень. Висновок щодо розробленої методики по валідаційному параметру “стабільність при розведенні" - коректна.

КЛЮЧОВІ СЛОВА: амлодипін; бісопролол; еналаприл; валідація; валідаційний параметр “стабільність при розведенні".

ВСТУП. Одним із найважливіших етапів створення лікарських засобів $€$ доклінічні та клінічні випробування, належне проведення яких гарантує в подальшому безпечність і високу терапевтичну ефективність розроблених лікарських засобів. Ключовим елементом доклінічних досліджень є різні фрармакологічні методики, при використанні яких здійснюють ряд аналітичних вимірювань на тих чи інших біологічних об'єктах. Тому ці методики класифрікують як біоаналітичні.

Біоаналітична методологія $€$ основоположником досліджень з вивчення біоеквівалентності й терапевтичного моніторингу лікарських засос Л. С. Логойда, 2019 бів, тому основну увагу при вивченні фрармакокінетики та біоеквівалентності потрібно приділяти розробці й валідації біоаналітичних методик аналізу.

Для отримання достовірних результатів, що можуть бути задовільно інтерпретовані, необхідно належним чином охарактеризувати біоаналітичні методики, які використовують, повністю їх валідувати і задокументувати. Дослідження 3 питань валідації доволі добре представлено в наукових працях учених, але аналіз публікацій свідчить про те, що здебільшого порушуються та розкриваються питання валідації біоаналітичних методів визначення різних аналітів у біоло- 
гічних рідинах за допомогою рідинної хроматограсрії та мас-спектроскопії [1-6]. Таким чином, набувають актуальності питання, пов'язані 3 визначенням особливостей процесу валідації біоаналітичних методів, які використовують під час доклінічних фрармакологічних досліджень лікарських засобів та розробки уніфрікованих підходів до проведення таких валідаційних робіт.

Мета дослідження - провести експериментальне вивчення валідаційного параметра "стабільність при розведенні” аналітичної методики кількісного визначення амлодипіну, бісопрололу та еналаприлу в плазмі крові для виконання фрармакокінетичних досліджень.

МЕТОДИ ДОСЛІДЖЕННЯ. Об'єктами дослідження були амлодипін, бісопролол та еналаприл.

У кожну пробірку вносять по 50 мкл кожного розчину QC-зразків та 50 мкл розчинів кожного внутрішнього стандарту в 450 мкл бланкової плазми. Пробірки закривають та перемішують їх вміст на шейкері протягом 10 с. Вносять 50 мкл розчинів внутрішніх стандартів у 0,5 мл плазми, струшують 4 хв. Осадження білків проводять шляхом додавання 1,5 мл ацетонітрилу та струшування впродовж 4 хв, потім центрифругування при 4000 об./Хв при $5{ }^{\circ} \mathrm{C}$ протягом 10 хв. До 1 мл прозорого розчину додають 1 мл води та виконуютьхроматограсрування. Пробихроматограсрують в ізократичному режимі з використанням хроматограсрічної колонки Eclipse C18, 100×4,6 мм, 3 розміром часток 3,5 мкм. Рухома фраза: ацетонітрил - 0,01 \% розчин кислоти мурашиної (100:0,1, v/v). Швидкість потоку - 0,7 мл/хв. Температура термостата колонки $-30^{\circ} \mathrm{C}$. Об'єм проби, яку вводять, -5 мкл.

РЕЗУЛЬТАТИ Й ОБГОВОРЕННЯ. БіоанаЛітична методика визначення амлодипіну, бісопрололу та еналаприлу ґрунтується на BEPX/ MC/MC аналізі аналітів у досліджуваних розчинах, отриманих із зразків плазми після попереднього осадження білків. Придатність біоаналітичної методики була підтверджена валідаційними характеристиками, які висувають до біоаналітичних методик $[7,8]$. У цій роботі описано валідаційний параметр "стабільність при розведенні". Розроблено електронні протоколи з використанням Microsoft Excel, в яких передбачено поля для введення даних.

Для розробки процедури визначення та оцінки dilution integrity виконано модельний експеримент. Результати вивчення валідаційного параметра "стабільність при розведенні" наведено в таблицях 1-3.

Таблиця 1 - Результати вивчення валідаційного параметра “стабільність при розведенні” аналітичної методики кількісного визначення амлодипіну

\begin{tabular}{||l|c|c|}
\hline \multicolumn{1}{|c|}{ Розведення } & $\times 2$ & $\times 4$ \\
\hline Концентрація амлодипіну, нг/мл & 8,00 & 8,00 \\
\hline Меап, \% & 8,08 & 8,91 \\
\hline Правильність, \% & 101,01 & 111,42 \\
\hline CV, \% & 6,71 & 2,76 \\
\hline $\begin{array}{l}\text { Відповідність критеріям } \\
\text { прийнятності }\end{array}$ & Правильність та прецизійність & методики \\
\hline
\end{tabular}

Таблиця 2 - Результати вивчення валідаційного параметра “стабільність при розведенні" аналітичної методики кількісного визначення бісопрололу

\begin{tabular}{|l|c|c|}
\hline \multicolumn{1}{|c|}{ Розведення } & $\times 2$ & $\times 4$ \\
\hline Концентрація бісопрололу, нг/мл & 40,00 & 40,00 \\
\hline Меап, \% & 40,40 & 38,43 \\
\hline Правильність \% & 101,01 & 96,08 \\
\hline CV, \% & 8,90 & 6,62 \\
\hline $\begin{array}{l}\text { Відповідність критеріям } \\
\text { прийнятності }\end{array}$ & Правильність та прецизійність & $< \pm 15 \%$ \\
методики & Відповідає \\
\hline
\end{tabular}

Таблиця 3 - Результати вивчення валідаційного параметра "стабільність при розведенні" аналітичної методики кількісного визначення еналаприлу

\begin{tabular}{||l|c|c|}
\hline \multicolumn{1}{|c|}{ Розведення } & $\times 2$ & $\times 4$ \\
\hline Концентрація еналаприлу, нг/мл & 400,00 & 400,00 \\
\hline Меап, \% & 402,31 & 405,98 \\
\hline Правильність, \% & 100,58 & 101,50 \\
\hline СV, \% & 6,46 & 7,21 \\
Відповідність критеріям & Правильність та прецизійність & $< \pm 15 \%$ \\
\hline
\end{tabular}


Як свідчать результати, наведені в таблицях 1-3, розведення зразків не вплинуло на правильність та прецизійність розробленої методики. Значення аналізу для всіх аналітів перебувають у межах критеріїв прийнятності. Висновок щодо розробленої методики по валідаційному параметру "стабільність при розведенні" коректна. Валідаційний параметр "стабільність при розведенні» (dilution integrity) незаслужено обділено увагою в керівництвах з валідації біоаналітичних методик - можливість розведення зразків дозволяє звужувати діапазон застосування методики і використовувати для калібрування більш просту модель, отримувати кращі показники лінійності, правильності та прецизійності; розробляти методику для низьких концентрацій і використовувати її як універсальну.

ВИСНОВКИ. 1. Проведено експериментальне вивчення валідаційного параметра "стабільність при розведенні" аналітичної методики кількісного визначення амлодипіну, бісопрололу та еналаприлу в плазмі крові для виконання фрармакокінетичних досліджень.

2. Висновок щодо розробленої методики по валідаційному параметру “стабільність при розведенні" - коректна.

\section{СПИСОК ЛІТЕРАТУРИ}

1. A strategy for validation of bioanalytical methods / S. Braggio, R. J. Barnaby, P. Grosi, M. Cugola // Journal of Pharmaceutical and Biomedical Analysis. - 1996. - 14, No. 4. - P. 375-388.

2. Singh U. K. Bioanlytical method development and validation / U. K. Singh, P. Pandey, P. K. Keshri // J. Biorg. Chem. - 2000. - 2. - P. 34-45.

3. Causon R. Validation of chromatographic methods in biomedical analysis viewpoint and discussion / R. Causon // J. Chromatogr. B. - 1997. - 689, No. 1. - P. 175180.

4. SharmaA. Bioanalytical Method development and Validation of Drugs in Biological fluid / A. Sharma, S. Rathore // Int. J. of Pharm \& Research Sci. - 2012. - 1, No. 4. - P. 216-226.

\section{REFERENCES}

1. Braggio, S., Barnaby, R.J., Grosi, P., \& Cugola, M. (1996). A strategy for validation of bioanalytical methods. Journal of Pharmaceutical and Biomedical Analysis, 14 (4), 375-388.

2. Singh, U.K., Pandey, P., \& Keshri, P.K. (2000). Bioanlytical method development and validation. Biorg. Chem., 2, 34-45.

3. Causon, R. (1997). Validation of chromatographic methods in biomedical analysis viewpoint and discussion. J. Chromatogr. B., 689 (1), 175-180.

4. Sharma, A., \& Rathore, S. (2012). Bioanalytical method development and validation of drugs in biological fluid. Int. J. of Pharm \& Research Sci., 1 (4), 216-226.

5. James, C.A., Breda, M., \& Frigerio, E. (2004). Bioanalytical method validation: a risk-based approach.
5. James C. A. Bioanalytical method validation: a risk-based approach / C. A. James, M. Breda, E. Frigerio // Journal of Pharmaceutical and Biomedical Analysis. - 2004. - 35, No. 4. - P. 887-889.

6. Bioanalytical method development and validation by using Lc-Ms/Ms / S. Murugan, N. Pravallika, P. Sirisha, K. Chandrakala // Journal of Chemical and Pharmaceutical Sciences. - 2013. - 6, No. 1. - P. 41-45.

7. Валидация биоаналитического метода : метод. рек. / ГП "Государственный экспертный центр". - К., 2013. -35 c.

8. Logoyda L. The methods for determination of combination antihypertensive drugs in human plasma by HPLC MS/MS / L. Logoyda, D. Korobko, S. Kovalenko // $23^{\text {nd }}$ Dubai International Pharmaceuticals \& Technologies Conference \& Exhibition, (February 27-March 01), 2018. Dubai, 2018. - P. 40.

Journal of Pharmaceutical and Biomedical Analysis, 35 (4), 887-889.

6. Murugan, S., Pravallika, N., Sirisha, P., \& Chandrakala, K. (2013). Bioanalytical method development and validation by using LC-MS/MS. Journal of Chemical and Pharmaceutical Sciences, 6 (1), 41-45.

7. (2013). Validatsiya bioanaliticheskogo metoda: metod. rekomendatsii [Validation of the bioanalytical method: method. recommendations]. Kyiv: GP "Gosudarstvennyy ekspertnyy tsentr" [in Ukrainian].

8. Logoyda, L., Korobko, D., \& Kovalenko, S. (2018). The methods for determination of combination antihypertensive drugs in human plasma by HPLC MS/MS. $23^{\text {nd }}$ Dubai International Pharmaceuticals \& Technologies Conference \& Exhibition, (February 27 - March 01), Dubai, p. 40. 


\section{ПРОЦЕДУРА ИЗУЧЕНИЯ ВАЛИДАЦИОННОГО ПАРАМЕТРА “СТАБИЛЬНОСТЬ ПРИ РАЗВЕДЕНИИ” АНАЛИТИЧЕСКОЙ МЕТОДИКИ КОЛИЧЕСТВЕННОГО ОПРЕДЕЛЕНИЯ НЕКОТОРЫХ АНТИГИПЕРТЕНЗИВНЫХ АНАЛИТОВ В БИОЛОГИЧЕСКИХ ЖИДКОСТЯХ ДЛЯ ПРОВЕДЕНИЯ ФАРМАКОКИНЕТИЧЕСКИХ ИССЛЕДОВАНИЙ}

\section{Резюме}

Вступление. Биоаналитическая методология является основоположником исследований по изучению биоэквивалентности и терапевтического мониторинга лекарственных средств, поэтому основное внимание при изучении фрармакокинетики и биоэквивалентности нужно уделять разработке и валидации биоаналитических методик анализа.

Цель исследования - провести экспериментальное изучение валидационного параметра "стабильность при разведении" аналитической методики количественного определения амлодипина, бисопролола и эналаприла в плазме крови для выполнения фрармакокинетических исследований.

Методы исследования. Биоаналитическая методика определения амлодипина, бисопролола и эналаприла основывается на ВЭЖХ/МС/МС анализе аналитов в исследуемых растворах, полученных из образцов плазмы после предварительного осаждения белков.

Результаты и обсуждение. В этой работе описано валидационный параметр "стабильность при разведении". Разработаны электронные протоколы с использованием Microsoft Excel, в которых предусмотрены поля для ввода данных. Для разработки процедуры определения и оценки dilution integrity выполнен модельный эксперимент. Бланковые образцы плазмы разбавляли 2- и 4-кратные разведения при шести определениях. Разведение образцов не повлияло на правильность и прецизионность разработанной методики. Валидационный параметр "стабильность при разведении" (dilution integrity) незаслуженно обделен вниманием в руководствах по валидации биоаналитических методик - возможность разведения образцов позволяет сужать диапазон применения методики и использовать для калибровки более простую модель, получать лучшие показатели линейности, правильности и прецизионности; разрабатывать методику для низких концентраций и использовать ее как универсальную.

Выводы. Проведено экспериментальное изучение валидационного параметра "стабильность при разведении" аналитической методики количественного определения амлодипина, бисопролола и эналаприла в плазме крови для выполнения фрармакокинетических исследований. Вывод относительно разработанной методики по валидационному параметру “стабильность при разведении" - корректна.

КЛЮЧЕВЫЕ СЛОВА: амлодипин; бисопролол; эналаприл; валидация; валидационный параметр "стабильность при разведении".

\section{PROCEDURE FOR THE STUDY OF VALIDATION PARAMETER “DILUTION INTEGRITY” OF ANALYTICAL METHODOLOGY OF QUANTITATIVE DETERMINATION OF SOME ANTIHYPERTENSIVE ANALYTES IN BIOLOGICAL LIQUIDS FOR PHARMACOKINETIC STUDIES}

\section{Summary}

Introduction. Bioanalytical methodology is the founder of research on bioequivalence and therapeutic drug monitoring, so the focus of the study of pharmacokinetics and bioequivalence should be given to the development and validation of bioanalytical methods of analysis.

The aim of the study - to learn experimentally the validation parameter "dilution integrity" of analytical methods for quantitative determination of amlodipine, bisoprolol and enalapril in blood plasma for pharmacokinetic studies. 
Research Methods. The bioanalytical method for the determination of amlodipine, bisoprolol and enalapril is based on HPLC/MS/MS analysis of analytes in investigated solutions obtained from plasma samples after preprecipitation of proteins.

Results and Discussion. This paper describes the validation parameter "dilution integrity". Developed electronic protocols using Microsoft Excel, which provide fields for data entry. To develop a procedure for determining and evaluating dilution integrity a model experiment was performed. In this work, the validation parameter "dilution integrity" is described. We developed electronic protocols using Microsoft Excel, which provides fields for data entry. To develop a procedure for determining and evaluating dilution integrity we performed a model experiment. Blank samples of plasma diluted 2- and 4-fold dilutions with six determinations. The dilution of the samples did not affect the accuracy and precision of the developed methodology. Validation parameter "dilution integrity" is undeservedly deprived of attention in the guides on the validation of bioanalytical techniques - the possibility of dilution of samples allows narrowing the range of application of the method and apply for calibration a simpler model and receive better indicators of linearity, correctness and precision; to develop a technique for the field of low concentrations and use it as a universal one.

Conclusions. The study "dilution integrity" of the quantitative determination of amlodipine, bisoprolol and enalapril in blood plasma for pharmacokinetic studies was researched. Conclusion regarding the developed method according to the validation parameter "dilution integrity" is correct.

KEY WORDS: amlodipine; bisoprolol; enalapril; validation; "dilution integrity"

Отримано 08.04.19

Адреса для листування: Л. С. Логойда, Тернопільський державний медичний університет імені І. Я. Горбачевського, майдан Волі, 1, Тернопіль, 46001, Україна, e-mail: logojda@tdmu.edu.ua. 